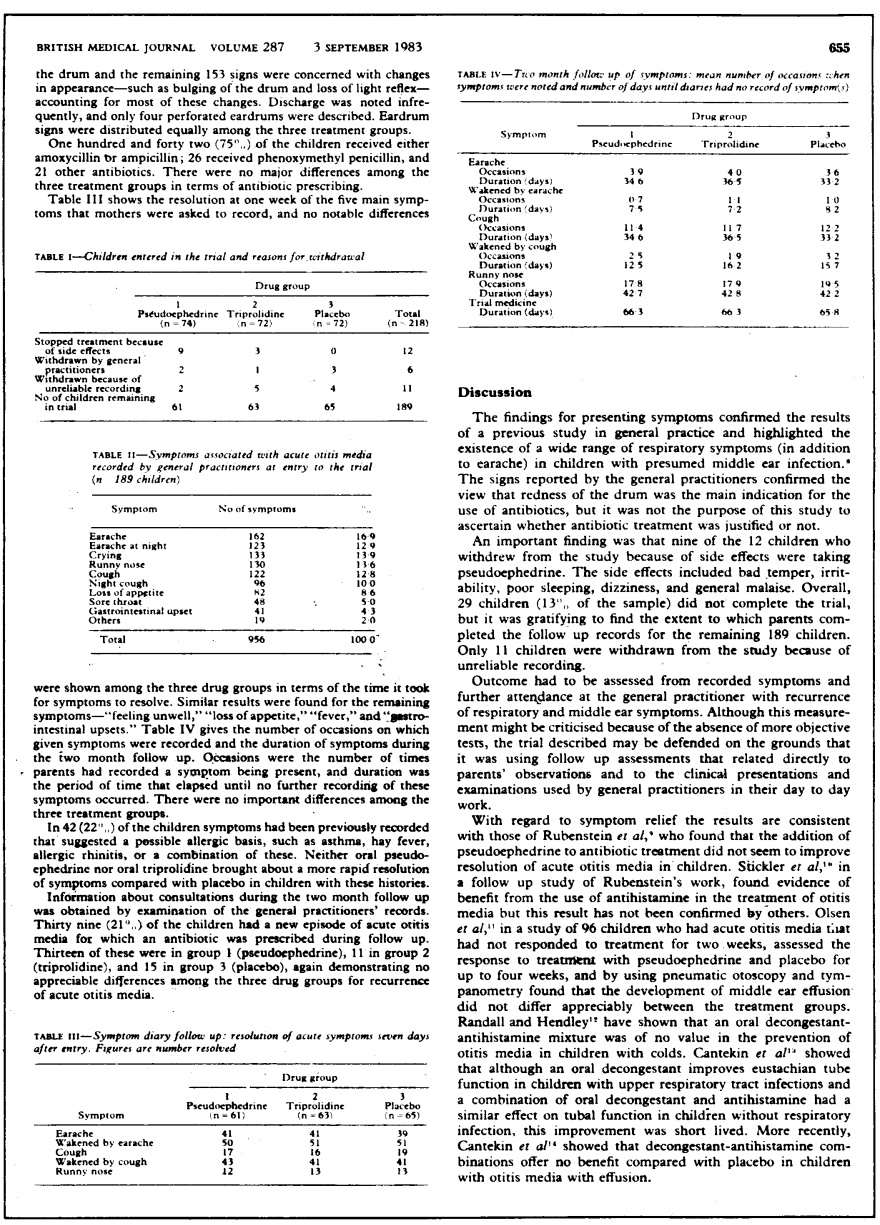

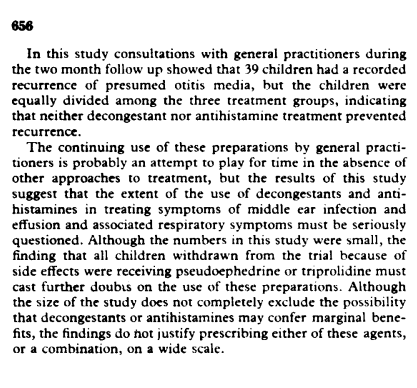

Conclusions
A double blind randomised control trial of treatment with a decongestant and an antihistamine was conducted in general
practicin in igs children with acute totitis media to decermine
whether such drugs reduced the duration and severity of assowhether such drugs reduced the duration and severity of asso-
ciated symptoms and prevented the recurrence of acute episodes.
After an acute atrack in addition to antibioticic treatment childen Areceived an eneight week cuurse of pseudoepheredrine, triprolidinine,
or placebo. There was no appreciable improvement among the three treatment groups in terms of symptom releief or time
taken for symptoms to resolve nor was there any difference in
the recurrence rate of acute ofitis the recurrence rate of acute otitis media. Side effects were found
more offen in those who received pseudoephedrine or triproli-
dine than in those who received placebo. The findings do not dine than in those who received placebo. The findings do not
justify yidespread prescribing of decongestants or antihistamines
in ihe management of children with acute otitis media.

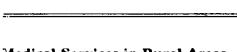

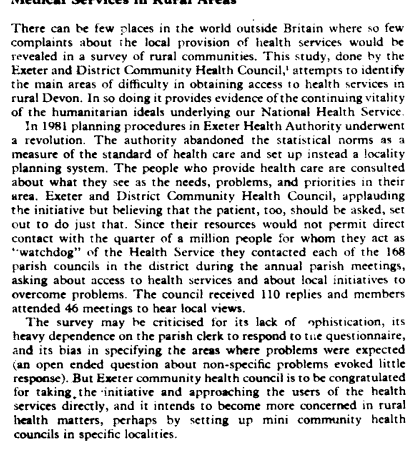

\begin{tabular}{|l|l|l} 
BRITISH MEDICAL JOURNAL VOLUME 287 & 3 SEPTEMBER 1983 \\
\hline
\end{tabular}

\title{
Innovations
}

\section{Have bus, won't travel!}

BRIAN R MCAVOY

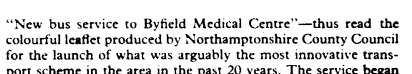

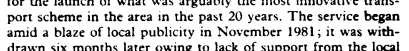
community.
This is an account of how and why that bus service came into being, and what happened when It was introduced and subse-
quently withdrawn. It raises several questions, and challenges
established views on transport in rural areas. Why did the service established views on transport in rural areas. Why did the service
fail? Who should be responsible for organising transport to fall? Who should be responsible for organising transport to
doctors' surgereies? How necessary is public transport in rural
arcas? ? I will try to answer these questions in the light of our Our three man practice covers 160 square miles in three
counties (Northamptonshire, Oxfordshire, and Warwickshire) counties (Northamptonshirce, Oxford dhire, and Warwickshire),
23 parishes, and 31 villages, with populations ranging from
20 ot iust under 2000 . We dispense for two thirds of our 5600 patients and provide our own out of hours cover.
Until 1980 we practised from an increasingly overcrowded
main surgery in Byfield- the centre of our seven mile radius main surgery in Byfield-the centre of our seven mile radius
practice area. We calo operated seven branch surgereis, six of
which were held for half to one hour a week and one for one which were held for half to one hour a week and one for onc
hour a weekday; most of these were only two or three miles
from Byficidd Since the branch surgeries provided inadequate facilities and
were more "ports of call" we resolved to close them and cen-
realise our service in a new medical centre that we decided io were more "ports of call" we resolved to close them and ced
tratise our service in a new medical centre that we decided to
build in Byfield. Despite considerable local opposition, the build in Byfield. Despite considerable local opposition, the
family practitioner committec approved our application to clos
five of the six branch surgeries. Transport scheme

Our practice area is poorly served by public transport, and
we realised that one concern about centralising our facilities

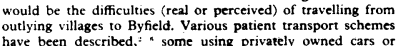
have been described, : "some using privately owned cars or
minibuses, onthers school busese and ambulances. We sudied
these schemes in detail and decided that the most appopriase these schemes in detail and decided that the most appropriate
system for our local circumstances would be a coach operating
a round trip from the outlying villages to che central surgery. a round trip from the outlying villages to the central surgery.
We contacted the Northamptonshire County Council High
ways and Transportation Department asking if they could help

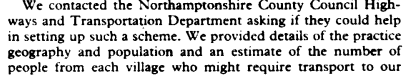

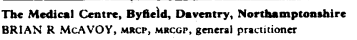

BRITISH MEDICAL JOURNAL VOLUME $287 \quad 3$ SEPTEMBER 1983

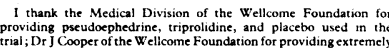

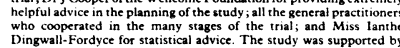
a grant from the Scotrish Hospitals Endowment Rescarch Trust. I am alsograteful to Moss Helen Thomson and Mrs Margare
McGregor for following up the children in the study.

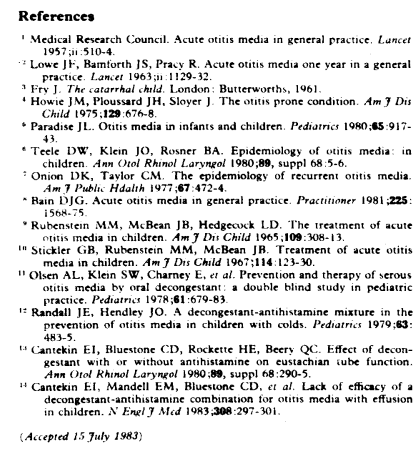
Accepped 15. 7uly 1983
658

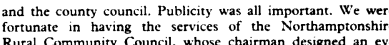
fortunate in having the services of the Northamptonshire
Rural Community Council, whose chairman designed an eye
carching leaflet-timetable that was kindly printed by the county council. The rural community council also organised a com-
petition in the local primary schools with a prize for the besis poster advertitising the new bus service. The local newspaper
and television were kept informed by the county council and
provided publicicty before the launch. Wc sent a letter explaining provided publicity before the launch. Wc sent a letter explainin
the new service and its need for support to the local parish and the new service and its need for support to the local parish ard
district councilis, commununity health councils, family prac-
titioner commitrees, and clergy. In all these forms of put titioner commitrees, and cletgyy In all these forms of pub-
licity we scrupulously avoided being mentioned by name or licity we scrupulously avoided being mentioned by name or
"advertisin" the services we offered. Finanlly, copies of the
timetable were distributed to the parish councils and all the village shops and post offices at the beginning of November.
Despiti all the publicity only five passengers travelled on the
first two journcys of the coach. The largest number of Despite all the publicity only five passengers travelled on the
first two journeys of the coach. The largest number of pas-
sengers- 17 - 17 came the following weck but during the whole of sengers-17-came the following week but during the whole of
December only seven people used the bus during irs 10 juorncys.
Further appeals for support were made in the local press coupled Further appeals for support were made in the local press coupled
with pessimistic statements from county council spokesme regarding the future of the subsidy. Despite this, the numbers
using the bus service ach weer remained in single figurse. On
several journeys the bus travelled the whole route and back several journeys the bus travelled the whole route and back
empty. As the month went hy the number of people using the
bus service averaged out at tour a week or two a jounney. To bus service averaged out at tour a week or two a ourney. To
meet the county council criterion for subsidising rural bus

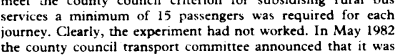

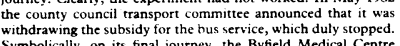
withdrawing the subsidy for the bus service, which duly stopped.
Symbolically, on irs final journey, the Byyield Medical Centre
bus was empty. It wad been an expensive experiment. The total subsidy over
the six months amounted to nearly $\_1250$. On many journeys the six months amounted to nearly 61250 . On many journeys
the sole passenger was being transported at a cost to the local It is now almost one year siace the bus service was withdrawn
When the county council officially informed the parish councils that the bus service was being stopped it suggested that they
might inke to vonsider setting up social car schemes, and
offered help with advice and administrative cosss. Several might like to consider setting up social car schemes, and
offered help with advice and administrative costs. Seeveral
parish councilis have caken un this lead and now succestuly peprate such schemes. W'e continue to see our patients who live
in the outlying villages at our central surtegry. There is no
evidence that patients have difficulty travelling to the surgery, evidence that patiens have difficulty travelling to the surgery,
and there has been no increase in the number of home visits
we make to these villages.

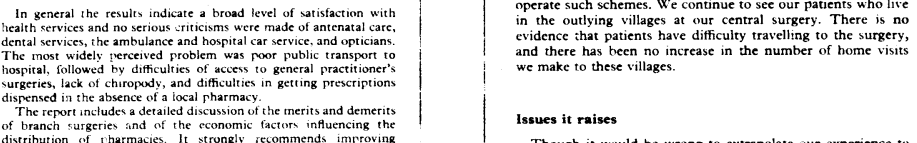

Though it would he wrong to extrapolate our experience to
all rural practices in Britaing I Inevertheless think that it raises
issues that are of more than local interest. The assumptions that issues that are of more than local interest. The assumptions that
any reduction in rural services including branch surgeries and
public transport is "bad," and that providing a bus for patients

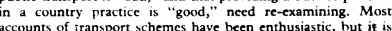
accounts of rransport schemes have been enthusiastic, but it is
noteworthy that four of the frue practices secscribed in Lance's
paper' discontinued their transport services shortly after the

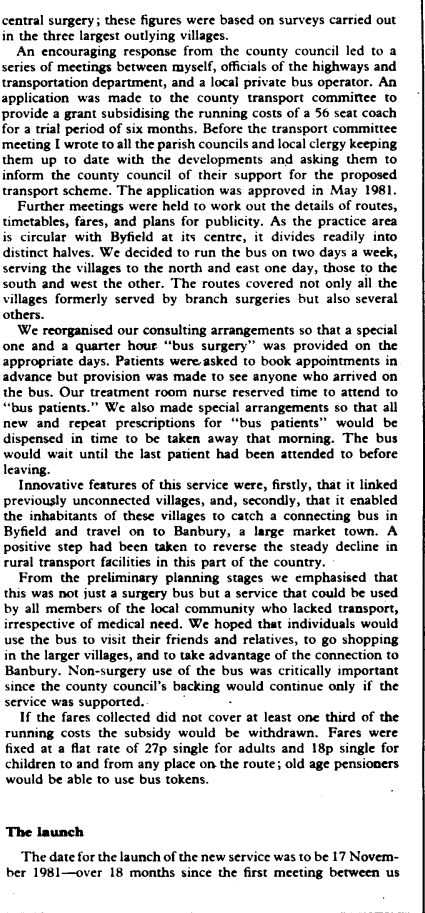

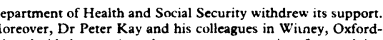

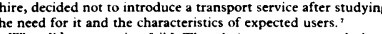

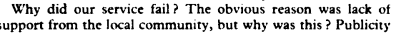

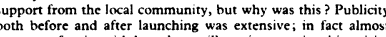

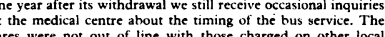

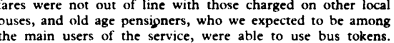

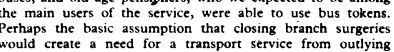

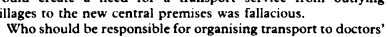

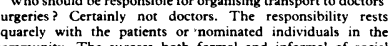

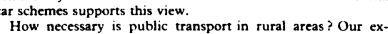

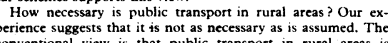

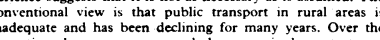

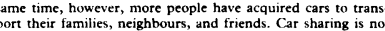

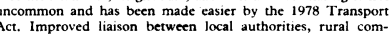

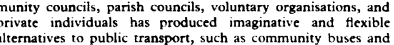

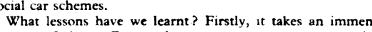

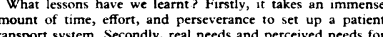

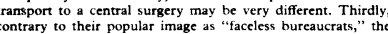

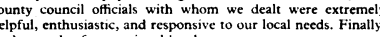

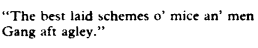

I thank Dr P H Middleton, Dr D F Burton, and Dr R C Fraser for
dvice and support

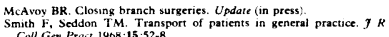

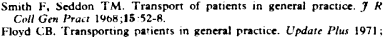

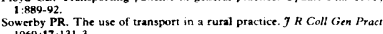

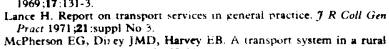

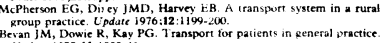
[Accepred 17 May 1983] 